\title{
Large cystic ductal carcinoma of the prostate: imaging findings and minimally invasive surgical treatment
}

Fabio Cesar Miranda Torricelli, ${ }^{1}$ Marcos Tucherman, ${ }^{2}$ Rodrigo Melogno, ${ }^{3}$ Rafael Ferreira Coelho ${ }^{1,2}$

${ }^{1}$ University of São Paulo Medical School, São Paulo, Brazil

${ }^{2}$ Hospital Israelita Albert Einstein, São Paulo, Brazil ${ }^{3}$ Hospital Britanico, Montevideo, Uruguay

\section{Correspondence to}

Dr Rafael Ferreira Coelho, coelhouro@yahoo.com.br

Accepted 12 November 2014

\section{DESCRIPTION}

Prostatic ductal carcinoma (PDC) is a rare histological subtype of prostate cancer usually diagnosed in a more advanced stage, presenting with a higher mortality rate than acinar prostate carcinoma. ${ }^{1-3}$

A 65 -year-old asymptomatic man presented with a pelvic cystic lesion diagnosed during a routine ultrasound. The prostate specific antigen (PSA) level was $3.5 \mathrm{ng} / \mathrm{mL}$ and digital rectal examination revealed a large cystic mass in the prostate topography. MRI showed a large multiloculated contrast-enhanced cystic lesion with thick septations arising from the retroprostatic and left pararectal space $(6.5 \times 5.0 \times 5.0 \mathrm{~cm}$; figure 1). Prostate biopsy revealed a prostatic acinar carcinoma in 1 of 14 cores (Gleason 7) located in the right mid, associated with a PDC in 3 of 14 cores

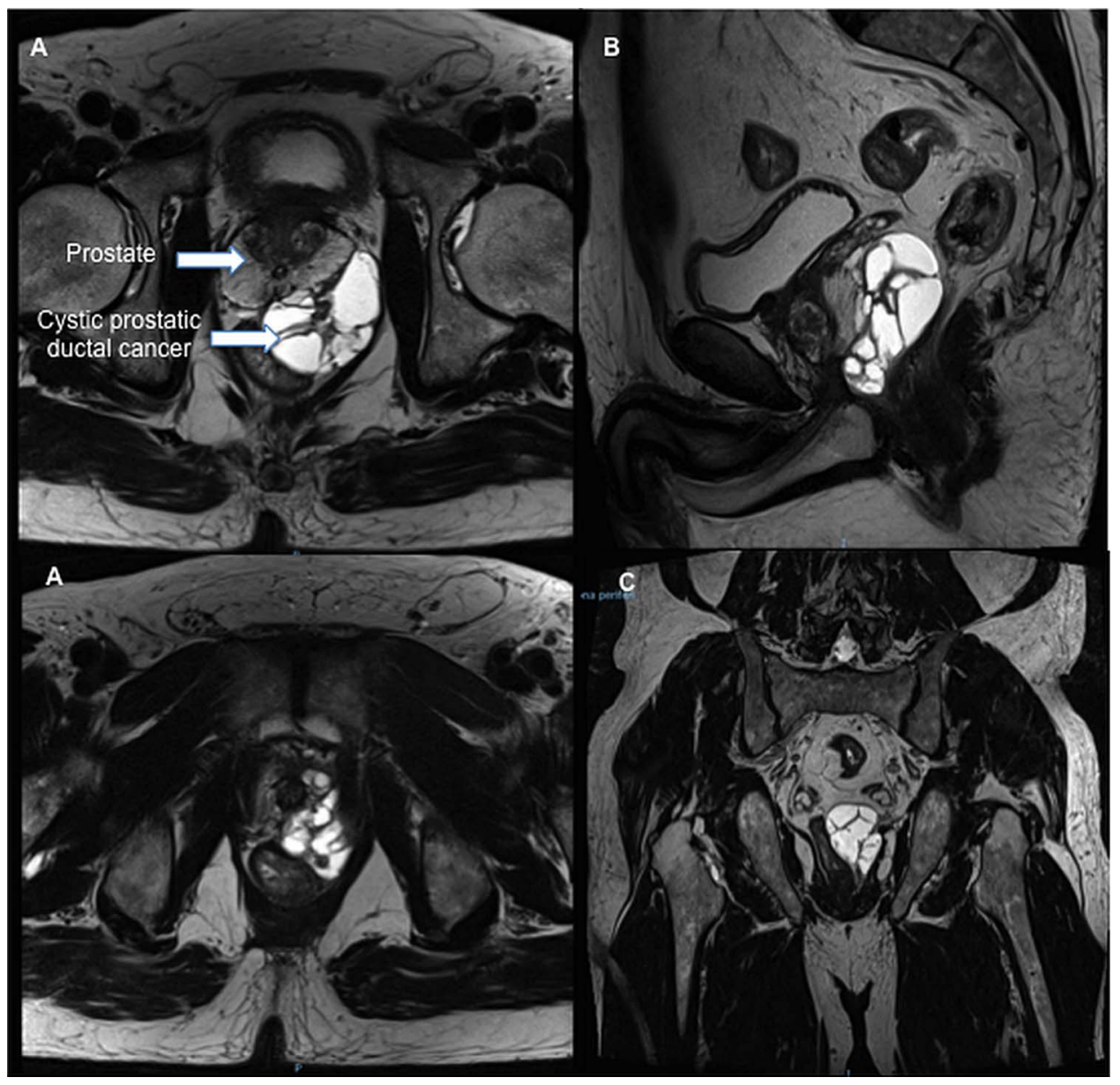

CrossMark

Figure 1 MRI showing a large multiloculated contrast-enhanced cystic lesion. (A) Axial view, (B) sagittal view and (C) coronal view.

To cite: Torricelli FCM, Tucherman M, Melogno R, et al. BMJ Case Rep Published online: [please include Day Month Year] doi:10.1136/bcr-2014207072 


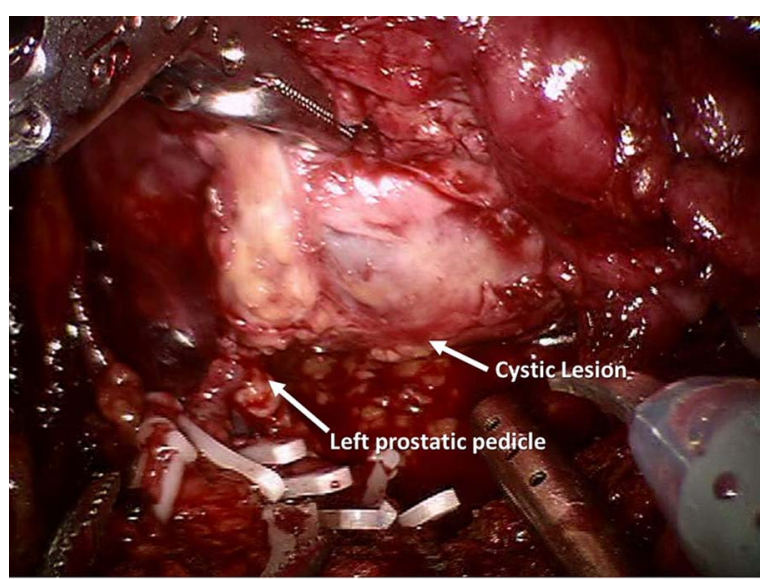

Figure 2 Intraoperative view.

located in the left lateral base of the prostate. Immunohistochemistry analysis was positive for PSA and $\alpha$-methylacyl coenzyme A racemase (AMACR). CT scan and bone scan were negative for metastasis. Based on these findings, the patient underwent a robotic-assisted

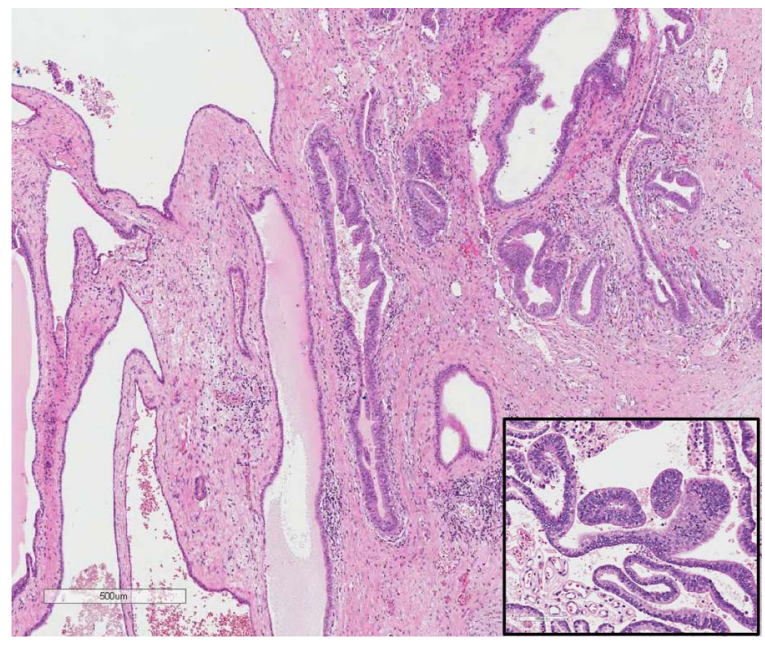

Figure 3 Pathological examination revealing large glands lined by tall, pseudostratified epithelium. laparoscopic prostatectomy with pelvic lymphadenectomy (figure 2). There were no intraoperative or postoperative complications. Pathological examination showed a prostatic acinar carcinoma Gleason $7(4+3)$ associated with a PDC in $30 \%$ of the gland with no positive lymph nodes $(0 / 20)$. Extensive extracapsular extension was present in the left base; the surgical margins were negative (pT3aN0; figure 3). After 12 months of follow-up the patient has no evidence of disease and serum PSA level is undetectable.

To the best of our knowledge, this is the first robotic-assisted prostatectomy for management of large PDC, showing that it is a treatment option for this uncommon condition.

\section{Learning points}

- Prostatic ductal carcinoma (PDC) is a rare histological subtype of prostate cancer.

- MRI is a useful tool for PDC diagnosis.

- Minimally invasive surgery is an option for treatment of this uncommon condition.

Acknowledgements The authors acknowledged Renee Zon Filippi, MDpathologist who reviewed the surgical specimen; and Giuliano Betoni Guglielmetti, MD—urologist who was involved with the patient's care.

Contributors FCMT drafted the article. MT contributed in the data acquisition. RM contributed in the data acquisition, conception and design. RFC performed critical revision for intellectual content.

Competing interests None.

Patient consent Obtained.

Provenance and peer review Not commissioned; externally peer reviewed.

\section{REFERENCES}

1 Meeks JJ, Zhao LC, Cashy J, et al. Incidence and outcomes of ductal carcinoma of the prostate in the USA: analysis of data from the Surveillance, Epidemiology, and End Results program. BJU Int 2012;109:831-4.

2 Sha J, Bo J, Pan J, et al. Ductal adenocarcinoma of the prostate: immunohistochemical findings and clinical significance. Onco Targets Ther 2013;6:1501-6.

3 Epstein Jl. Prostatic ductal adenocarcinoma: a mini review. Med Princ Pract 2010;19:82-5

Copyright 2014 BMJ Publishing Group. All rights reserved. For permission to reuse any of this content visit http://group.bmj.com/group/rights-licensing/permissions.

BMJ Case Report Fellows may re-use this article for personal use and teaching without any further permission.

Become a Fellow of BMJ Case Reports today and you can:

- Submit as many cases as you like

- Enjoy fast sympathetic peer review and rapid publication of accepted articles

- Access all the published articles

- Re-use any of the published material for personal use and teaching without further permission

For information on Institutional Fellowships contact consortiasales@bmjgroup.com

Visit casereports.bmj.com for more articles like this and to become a Fellow 